Nevada

Environmental

Restoration

Project

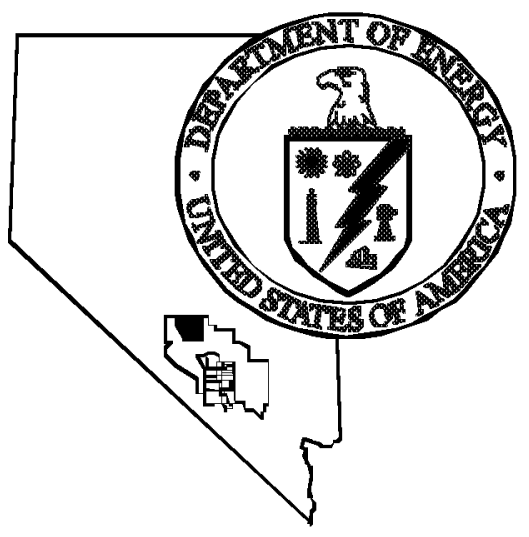

Closure Report for

Corrective Action Unit No. 427

Area 3 Septic Waste Systems 2 and 6

Tonopah Test Range, Nevada

Controlled Copy No.

Revision: 0

August 1999

Distribution A - Approved for publicrelease;furtherdissemination unlimited

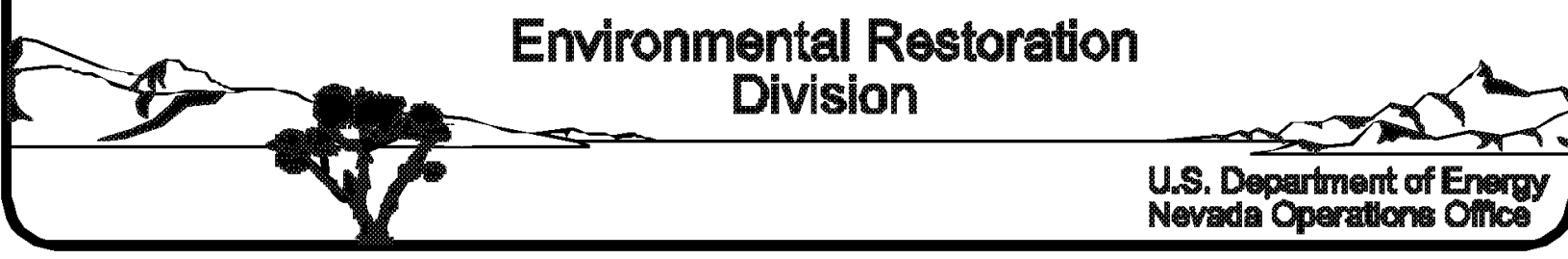


Available to the public from:

U.S. Department of Commerce

National Technical Information Service

5285 Port Royal Road

Springfield, VA 22161-0002

(703) $487-4650$

Available electronically at http://www.doe.gov/bridge. Available to U.S. Department of Energy and its contractors in paper form:

U.S. Department of Energy

Office of Scientific and Technical Information

P.O. Box 62

Oak Ridge, TN 37831-0062

(423) $576-8401$ 


\section{Closure Report for Corrective Action Unit 427: Area 3 Septic Waste Systems 2 and 6 Tonopah Test Range, Nevada}

Controlled Copy No.:

Revision: 0

Prepared for:

U. S. Department of Energy

Nevada Operations Office

Under Contract No. DE-AC08-96NV11718

August 1999 
THIS PAGE INTENTIONALLY LEFT BLANK 


\section{Closure Report for Corrective Action Unit 427: Area 3 Septic Waste Systems 2 and 6 Tonopah Test Range, Nevada} Approved by: $\frac{\text { Sabuce } T . C u r t s}{\begin{array}{c}\text { Janet L. Appenzeller-Wing, Project Manager } \\ \text { Industrial Sites Subproject }\end{array}}$ Date: $8 / 16 / 99$

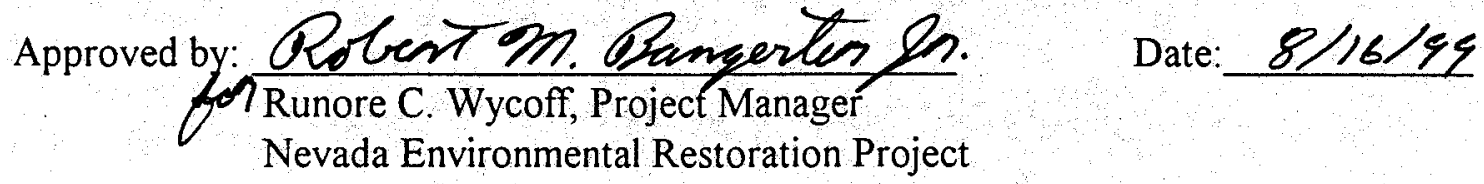


THIS PAGE INTENTIONALLY LEFT BLANK 
FIGURES $\ldots \ldots \ldots \ldots \ldots \ldots \ldots \ldots \ldots \ldots \ldots \ldots \ldots \ldots \ldots \ldots \ldots \ldots \ldots \ldots \ldots \ldots \ldots$ vi

APPENDICES $\ldots \ldots \ldots \ldots \ldots \ldots \ldots \ldots \ldots \ldots \ldots \ldots \ldots \ldots \ldots \ldots \ldots \ldots \ldots \ldots$ vi

ACRONYMS AND ABBREVIATIONS $\ldots \ldots \ldots \ldots \ldots \ldots \ldots \ldots \ldots \ldots \ldots \ldots \ldots \ldots$ vii

EXECUTIVE SUMMARY $\ldots \ldots \ldots \ldots \ldots \ldots \ldots \ldots \ldots \ldots \ldots \ldots \ldots \ldots \ldots \ldots \ldots$ ix

1.0 INTRODUCTION $\ldots \ldots \ldots \ldots \ldots \ldots \ldots \ldots \ldots \ldots \ldots \ldots \ldots \ldots \ldots \ldots \ldots \ldots \ldots \ldots 1$

1.1 Purpose $\ldots \ldots \ldots \ldots \ldots \ldots \ldots \ldots \ldots \ldots \ldots \ldots \ldots \ldots \ldots \ldots \ldots \ldots \ldots$

1.2 Scope $\ldots \ldots \ldots \ldots \ldots \ldots \ldots \ldots \ldots \ldots \ldots \ldots \ldots \ldots \ldots \ldots \ldots \ldots \ldots \ldots$

1.3 Contents $\ldots \ldots \ldots \ldots \ldots \ldots \ldots \ldots \ldots \ldots \ldots \ldots \ldots \ldots \ldots \ldots \ldots \ldots \ldots .4$

2.0 CLOSURE ACTIVITIES $\ldots \ldots \ldots \ldots \ldots \ldots \ldots \ldots \ldots \ldots \ldots \ldots \ldots \ldots \ldots \ldots 7$

2.1 Description of Corrective Action Activities $\ldots \ldots \ldots \ldots \ldots \ldots \ldots \ldots \ldots \ldots \ldots \ldots \ldots 7$

2.1.1 Installation of Markers and Warning Signs $\ldots \ldots \ldots \ldots \ldots \ldots \ldots \ldots \ldots 7$

2.2 Deviations from the Corrective Action Plan as Approved ...............

2.3 Corrective Action Schedule as Completed $\ldots \ldots \ldots \ldots \ldots \ldots \ldots \ldots \ldots \ldots \ldots \ldots \ldots 8$

2.4 Site Plan/Survey Plat $\ldots \ldots \ldots \ldots \ldots \ldots \ldots \ldots \ldots \ldots \ldots \ldots \ldots \ldots \ldots$

3.0 WASTE DISPOSITION $\ldots \ldots \ldots \ldots \ldots \ldots \ldots \ldots \ldots \ldots \ldots \ldots \ldots \ldots \ldots \ldots \ldots \ldots$

4.0 CLOSURE VERIFICATION RESULTS $\ldots \ldots \ldots \ldots \ldots \ldots \ldots \ldots \ldots \ldots \ldots \ldots \ldots 13$

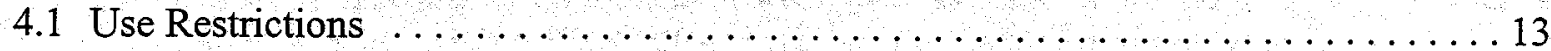

5.0 POST-CLOSURE INSPECTION PLAN $\ldots \ldots \ldots \ldots \ldots \ldots \ldots \ldots \ldots \ldots \ldots \ldots \ldots \ldots 15$

5.1 Post-Closure Inspection $\ldots \ldots \ldots \ldots \ldots \ldots \ldots \ldots \ldots \ldots \ldots \ldots \ldots \ldots \ldots \ldots \ldots$

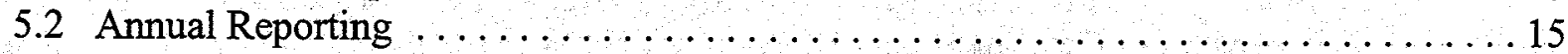

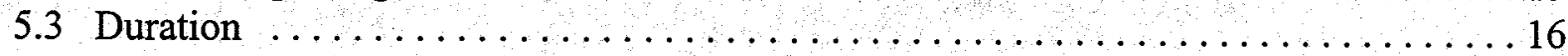

6.0 CONCLUSIONS AND RECOMMENDATIONS $\ldots \ldots \ldots \ldots \ldots \ldots \ldots \ldots \ldots \ldots \ldots \ldots 17$

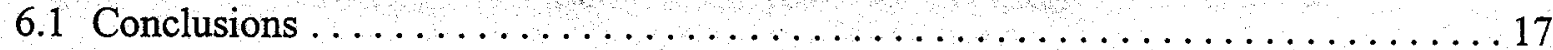

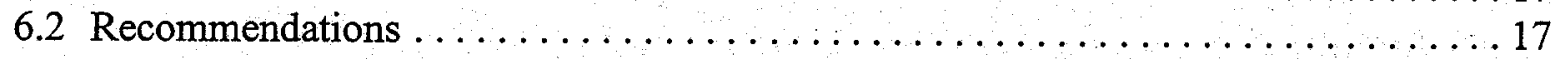

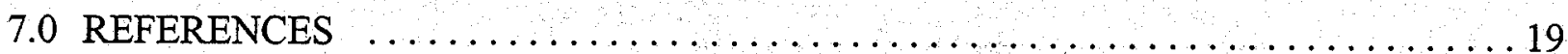

DISTRIBUTION LIST

COMMENT RESPONSES 


\section{FIGURES}

FIGURE 1 - Location of Area 3 Septic Waste Systems 2 and 6 Tonopah Test Range .......2

FIGURE 2 - CAU 427 Septic Waste Systems 2 and 6 Closure Activities Map .........3

FIGURE 3 - Corrective Action Schedule as Completed ..................9

FIGURE B-1 CAU 427 Septic Waste Systems $2 \& 2$ Site Plan $\ldots \ldots \ldots \ldots \ldots \ldots \ldots \ldots \ldots$ B-1

FIGURE E-1 Photo Documentation of January 21-22, 1999, Closure Activities,

Septic Tank 33-5/Liquefying the Solidified Septage Sludge . . .......... E-1

FIGURE E-2 Photo Documentation of January 21-22, 1999, Closure Activities,

Mixing the Septage with Water/Equipment Cleaning .............E-2

FIGURE E-3 Photo Documentation of January 21-22, 1999, Closure Activities,

Pumping Out the Septage/Liquefied Septage $\ldots \ldots \ldots \ldots \ldots \ldots \ldots$ E-3

FIGURE E-4 Photo Documentation of January 21-22, 1999, Closure Activities,

Washing the Septic Tank/Filling the Tank With.Clean Fill Material . . . . . . . E-4

FIGURE E-5 Photo Documentation of January 21-22, 1999, Closure Activities,

Sealing the Top of the Tank with Concrete/Restoring the Excavation to its

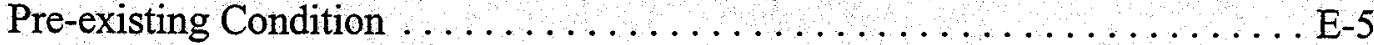

FIGURE E-6 Photo Documentation of June 29, 1999, Closure Activities, Placement of

Subsurface Markers at Use Restriction Boundaries/CAU 427 Warning Sign .. E-6

\section{APPENDICES}

APPENDIX A - SEPTAGE DISPOSAL DOCUMENTATION

APPENDIX B - ENGINEERING AS-BUILT DRAWINGS

APPENDIX C - USE RESTRICTION DOCUMENTATION

APPENDIX D - POST-CLOSURE INSPECTION PLAN AND MAINTENANCE RECORD

APPENDIX E - PROJECT PHOTOGRAPHS 


$\begin{array}{ll}\text { CADD } & \text { Corrective Action Decision Document } \\ \text { CAP } & \text { Corrective Action Plan } \\ \text { CAS } & \text { Corrective Action Site } \\ \text { CAU } & \text { Corrective Action Unit } \\ \text { CR } & \text { Closure Report }\end{array}$

DOE/NV U.S. Department of Energy, Nevada Operations Office

FFACO Federal Facility Agreement and Consent Order

gal gallon

L liter

NAC Nevada Administrative Code

NDEP Nevada Division of Environmental Protection

PAL Preliminary Action Level

PCB Polychlorinated Biphenly

RCRA Resources Conservation and Recovery Act

SVOC. Semivolatile Organic Compounds

SWS Septic Waste System

VOC Volatile Organic Compound 
THIS PAGE INTENTIONALLY LEFT BLANK 
This plan addresses the closure of Corrective Action Unit (CAU) 427 identified in the Federal Facility Agreement and Consent Order (FFACO). The site is located at the Tonopah Test Range, Area 3, Septic Waste Systems 2 and 6. The CAU consists of Corrective Action Sites 03-05-002-SW02 and 03-05-002-SW06, which include two septic waste systems, three septic tanks, and four associated leachfields.

Closure for this site was completed by the following:

- Excavating the soil covering Septic Tank 33-5 to provide access to the tank.

- Removing the solid and liquid septage from Septic Tank 33-5.

- Filling the septic tank with clean fill material and sealing the tank with concrete.

- Transporting and disposing of the septage.

- Placing permanent markers at the boundaries of each leachfield.

- Closing in-place with administrative controls.

As documented in this Closure Report, closure activities for CAU 427 have been completed following the Nevada Division of Environmental Protection (NDEP)-approved Corrective Action Plan (U.S. Department of Energy, Nevada Operations Office [DOE/NV], 1998b). The DOE/NV requests that:

- CAU 427 be moved from Appendix III to Appendix IV of the FFACO.

- NDEP provide a Notice of Completion to the DOE/NV. 
THIS PAGE INTENTIONALLY LEFT BLANK 


\subsection{INTRODUCTION}

This Closure Report (CR) provides documentation for the closure of Corrective Action Unit (CAU) 427 identified in the Federal Facility Agreement and Consent Order (FFACO). The site is located at the Tonopah Test Range Area 3 Septic Waste Systems (SWSs) 2 and 6 (Figure 1). The CAU consists of two Corrective Action Sites (CASs) 03-05-002-SW02 and 03-05-002-SW06, which include two septic systems, three septic tanks, and four leachfields (Figure 2).

The SWSs were installed to receive sanitary waste and industrial liquid wastes generated from site maintenance and other daily operations conducted at the Area 3 Compound (Corrective Action Decision Document [CADD]) (U.S. Department of Energy, Nevada Operations Office [DOE/NV], 1998a). SWSs 2 and 6 were in operation during different time intervals from 1960 through 1990. Process knowledge regarding the composition of the waste water is limited because disposal practices commonly associated with early operations are unknown (DOE/NV, 1998a). Specific details of the installation of subsurface components and the composition and condition of the collection system network were previously unknown.

Site investigation activities were completed in February 1998 and are documented in the CADD (DOE/NV, 1998a). The site characterization found septage in Septic Tank 33-5. Septic

Tank 33-4 is closed. Septic Tank 33-6 is still active and in line with the Sandia National Laboratories consolidated system. This site was investigated for volatile organic compounds (VOCs), semivolatile organic compounds (SVOCs), polychlorinated biphenyls (PCBs), Resource Conservation \& Recovery Act (RCRA) metals, and total petroleum hydrocarbons.

Characterization results of the three leachfields associated with these septic tanks were characterized and no PCBs, VOCs, SVOCs, or RCRA metals were detected above the Preliminary Action Levels (PALs). Arsenic was detected above PALs, but is considered to be associated with natural elevated background concentrations in the area. Samples were also analyzed using gamma spectroscopy.

PALs were agreed upon with the Nevada Division of Environmental Protection (NDEP) during the characterization data quality objectives process and are outlined in the Corrective Action Investigation Plan and referenced in the CADD (DOE/NV, 1998a). The Nevada Administrative Code (NAC) Action Level of 100 milligrams per kilogram for petroleum hydrocarbons was exceeded in samples taken from 1965-1975 Leachfield (Leachfield A), Abandoned Leachfield, and the outfall end of Septic Tank 33-4 (Figure 2). An (a) through (k) analysis was conducted (DOE/NV, 1998a). Based upon this analysis, the concentrations of petroleum hydrocarbons detected in the unit do not present a significant hazard to the environment or groundwater. Biological activity will likely result in reduced concentrations of petroleum hydrocarbons over time; therefore, the leachfields were closed in-place with administrative controls. Subsurface metal plates were placed at the comers of each use restricted area to simplify boundary detection (using a magnetometer or equivalent) while minimizing marker deterioration due to placement in high traffic areas. The need for unobstructed road access prompted the placement of warning signs in low traffic areas and subsurface boundary markers in high traffic areas. 

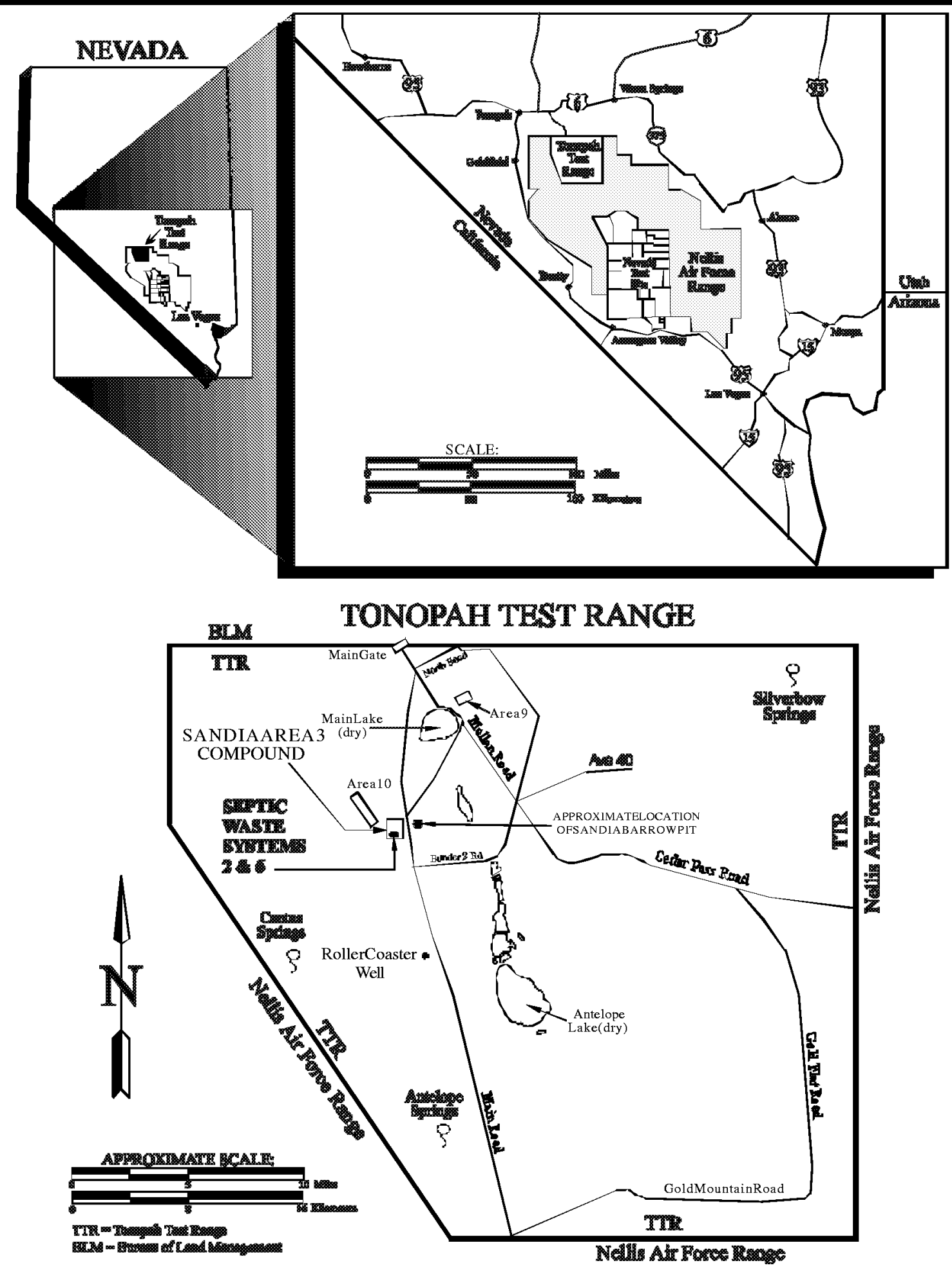

FIGURE 1

LOCATIONOFAREA3SEPTICWASTES YSTEMS $2 \& 6$ TONOPAHTESTRANGE 


\subsection{PURPOSE}

The purpose of this $\mathrm{CR}$ is to:

- Document the closure activities as proposed in the NDEP-approved Corrective Action Plan (CAP) (DOE/NV, 1998b).

- Provide a Post-Closure Inspection Plan.

- Obtain a Notice of Completion from the NDEP.

- Recommend the movement of CAU 427 from Appendix III to Appendix IV of the FFACO.

\subsection{SCOPE}

The following lists the scope of closure actions implemented at CAU 427:

- Excavating the soil covering Septic Tank 33-5 to provide access to the tank.

- Removing the septage from Septic Tank 33-5.

- Filling of the septic tank with clean fill material and sealing the tank with concrete.

- Transporting and disposing of the septage.

- Placing permanent markers at the boundaries of each use restricted area.

Closure of CAU 427 was completed following the NDEP-approved CAP (DOE/NV, 1998b). The CAP was based on site characterization and process knowledge of the historical site use (DOE/NV, 1998a).

\subsection{CONTENTS}

This $\mathrm{CR}$ is divided into the following sections:

- Section 1.0 - Introduction.

- Section 2.0 - Closure Activities.

- Section 3.0 - Waste Disposition.

- Section 4.0 - Closure Verification Results.

- Section 5.0 - Post-Closure Inspection Plan 
- Section 6.0 - Conclusions and Recommendations.

- Section 7.0 - References.

- Appendices

This $\mathrm{CR}$ was developed using information and guidance from the following documents:

- Corrective Action Decision Document for CAU 427:Area 3 Septic Systems 2 \& 6, Tonopah Test Range, Nevada, Revision 0, April 1998, DOE/NV--509.

- Corrective Action Plan for Corrective Action Unit 427: Area 3 Septic Waste Systems 2\& 6 Tonopah Test Range, Nevada, Revision 0, November 1998, DOE/NV/11718--248.

- Nevada Environmental Restoration Project; Health and Safety Plan, Revision 3, DOE/NV, 1998.

- Nevada Environmental Restoration Project, Industrial Sites, Quality Assurance Project Plan, Nevada Test Site, Revision 1, DOE/NV, 1996.

- Nevada Environmental Restoration Project, Project Management Plan, Revision 0, DOE/NV, 1994.

- Corrective Action Unit Work Plan,Tonopah Test Range,Nevada, 1996, DOE/NV-443.

- Final Environmental Impact Statement for the Nevada Test Site and Off-site Locations in the State of Nevada, Volume I, 1996, DOE/EIS 0243.

- Industrial Waste Quality Assurance Project Pian, 1996, DOE/NV-372. 
THIS PAGE INTENTIONALLY LEFT BLANK 


\subsection{CLOSURE ACTIVITIES}

This section of the CR details the specific activities involved in the closure of CAU 427: Area 3 , Septic Waste Systems 2 and 6, Tonopah Test Range, Nevada (CASs 03-05-002-SW02 and 03-05-002-SW06). This section also includes the rationale for deviations from the NDEPapproved CAP (DOE/NV, 1998b) and a detailed schedule of site activities, as completed.

\subsection{DESCRIPTION OF CORRECTIVE ACTION ACTIVITIES}

Before field activities began, the following pre-field activities were completed:

- Preparation of National Environmental Policy Act documentation.

- Preparation of the Site Specific Health \& Safety Plan.

- Preparation of the Field Management Plan.

The field activities/site remediation activities included the following:

- Excavating the soil covering Septic Tank 33-5 (to provide access to the tank).

- Removing the septage from Septic Tank 33-5.

- Filling the septic tank with clean fill material and sealing the tank with concrete.

- Transporting and disposing of the septage.

- Placing of warning signs and markers at the boundaries of each use restricted area.

- Closing in-place with administrative controls.

\subsubsection{INSTALLATION OF MARKERS AND WARNING SIGNS}

As noted in Section 2.1, warning signs and markers were placed at the boundaries of use restricted areas. Warning signs were posted in low traffic areas. Subsurface metal markers were placed in high traffic areas at approximately 0.9 meters ( 1 foot) below ground surface at each of the use restricted boundary corners (Appendix B-CAU 427 Septic Waste Systems 2 and 6 Site Plan). The subsurface markers were constructed out of a ferrous material to simplify detection with a magnetometer, or equivalent. 


\subsection{DEVIATIONS FROM THE CORRECTIVE ACTION PLAN AS APPROVED}

Septage removed from Septic Tank 33-5 was to be stored in B-25 boxes and/or 322-liter (L) (85 gallon [gal]) drums prior to disposal, as stated in the NDEP-approved CAP (DOE/NV, 1998a). The septage pump truck provided by a subcontractor holds up to $3,785 \mathrm{~L}(1,000 \mathrm{gal})$ of septage. The usage of a subcontractor's filler tank, in comparison to using B-25 boxes and/or up to $24322-\mathrm{L}$ (85-gal) drums, is deemed more cost-effective and therefore used.

Approximately 7,570 L (2,000 gal) of septage was removed and disposed. Disposal documentation is provided in Appendix A. No other deviations from the NDEP-approved CAP (DOE/NV, 1998a) were made.

\subsection{CORRECTIVE ACTION SCHEDULE AS COMPLETED}

The corrective action activities were completed in a timely manner.

Field activities were started on January 20, 1999. Septage removal was completed on January 21,1999 , and the tank was filled, sealed with concrete, and the area was backfilled. The septage was removed and disposed off-site. The placement of warning signs and markers was completed on June 29, 1999. A detailed schedule of the project activities as completed can be found in Figure 3.

\subsection{SITE PLAN/SURVEY PLAT}

Figure 1 provides the location of CAU 427 on the Tonopah Test Range. Figures 2 and Figure B-1 (Appendix B) provide the site layout and locations of warning signs/markers following removal of the septage. 


\section{FIGURE 3: CORRECTIVE ACTION SCHEDULE AS COMPLETED}

Mobilization to site: $1 / 21 / 1999$

\section{Corrective Actions}

Removal of Septage from Septic Tank 33-5 1/21/1999

Transportation of Septage by M \& K Enterprises 1/21/1999

Filling and Sealing Tank 33-5

$1 / 22 / 1999$

Disposal of Septage in Pahrump

$3 / 29 / 1999$

Restoration of surface site conditions

$1 / 22 / 1999$

CAU 427 Survey

$2 / 18 / 1999$

Demobilization 1:

$1 / 21 / 1999$

\section{Remobilization:}

$6 / 28 / 1999$

Placement of warning signs and markers

$6 / 28 / 1999$

Demobilization 2:

6/31/1999 
THIS PAGE INTENTIONALLY LEFT BLANK 


\subsection{WASTE DISPOSITION}

Waste generated from CAU 427 closure activities consisted of non-hazardous septage sludge, liquid septage from cleaning the Tank 33-5, personal protective equipment, and sanitary trash. The solid and liquid septage was disposed off-site. 
THIS PAGE INTENTIONALLY LEFT BLANK 


\subsection{CLOSURE VERIFICATION RESULTS}

CAU 427 was closed by removing the septage in Septic Tank 33-5, filling it with inert material, and sealing the tank with concrete. In conjunction with use restrictions and administrative controls, warning signs were posted and subsurface markers were placed at use restriction boundary corners. As stated in the NDEP-approved CAP (DOE/NV, 1998b), verification sampling was not required. Waste management data for the septage is based upon process knowledge and analytical data collected from the pre-field surveys (DOE/NV, 1998a).

\subsection{USE RESTRICTIONS}

The future use of land related to CAU 427 is restricted from any activity that may alter or modify the containment control as approved by the State of Nevada and identified in this CR, or other CAU 427 documentation, unless appropriate concurrence is obtained in advance. Use restriction documentation is provided in Appendix C. 
THIS PAGE INTENTIONALLY LEFT BLANK 


\subsection{POST-CLOSURE INSPECTION PLAN}

Post-closure inspection of CAU 427 use restricted land is intended to determine:

- If maintenance and repairs to the closed leachfield or septic tank soil and asphalt covers are needed.

- If maintenance and repairs to the closed leachfield and septic tank markers and warning signs are needed.

- If modifications to the use restriction administrative controls are needed.

- If termination of post-closure inspection can be proposed in the future.

\subsection{POST-CLOSURE INSPECTION}

The inspection will consist of annual (once per year) visual inspections of:

- The soil and asphalt cover for indications of subsidence, erosion, unauthorized use, etc.

- The leachfields and septic tank markers and warning signs to verify they are in-place, intact, and readable.

- The inspections will be documented on a checklist (Appendix D) and, if needed, with photography.

Repairs to the soil and asphalt covers, leachfield markers, and warning signs (i.e., repair, reposition, and/or replacement) may be required.

Inspections are not required after severe weather events such as heavy rainfall, flash floods, and high winds, because the leachfield waste is buried in the subsurface. However, any identified maintenance and repair requirements noted before or after the annual inspection will be remedied within 90 days of discovery and documented in writing at the time of repair.

\subsection{ANNUAL REPORTING}

An annual letter report will provide the inspector's observations of CAU 427's land-use restricted areas and describe modifications and/or repairs made to Leachfield A, Leachfield B, pre-1965 Leachfield, 1965-1975 Leachfield, and/or Septic Tank 33-5. The annual post-closure inspection report will be prepared and submitted to NDEP before the completion of the fiscal year in which the inspection was conducted. The annual reports will include the following information: 
- Discussion of observations.

- Inspection checklist and maintenance record (Appendix D).

- Conclusions and recommendations.

\subsection{DURATION}

The annual inspections will be performed for five years after the completion of closure activities, and will be documented on inspection forms.

Completion of post-closure inspection of CAU 427 may be proposed by the DOE/NV to the NDEP if after two consecutive years of visual inspections, indications of subsidence depression recurrences have not been detected. Completion of post-closure inspection may be proposed by DOE/NV to the NDEP within five years after the completion of closure activities. 


\subsection{CONCLUSIONS AND RECOMMENDATIONS}

\subsection{CONCLUSIONS}

Closure for this site was completed by the following:

- Excavating the soil covering Septic Tank 33-5 (to provide access to the tank).

- Removing the septage from Septic Tank 33-5.

- Filling the septic tank with clean fill material and sealing the tank with concrete.

- Transporting and disposing of the septage.

- Placing warning signs and subsurface markers at use restriction boundaries.

- Closing in-place with administrative controls.

$\mathrm{DOE} / \mathrm{NV}$ will continue to perform post-closure inspection of the site as indicated in Section 5.0 of this CR.

\subsection{RECOMMENDATIONS}

Since the closure activities for CAU 427 have been completed following the NDEP-approved $\mathrm{CAP}(\mathrm{DOE} / \mathrm{NV}, 1998 \mathrm{~b})$. as documented in this $\mathrm{CR}$, the DOE/NV requests:

- A Notice of Completion be provided by the NDEP to DOE/NV for the closure of CAU 427 (CAS Numbers 03-05-002-SW02 and 03-05-002-SW06).

- CAU 427 be moved from Appendix III to Appendix IV of the FFACO. 
I 


\subsection{REFERENCES}

\section{U.S. Department of Energy, Nevada Operations Office, see DOE/NV}

DOE/NV, 1994. Nevada Environmental Restoration Project, Project Management Plan, Revision 0, DOE, 1994.

DOE/NV, 1996a. Corrective Action Unit Work Plan, Tonopah Test Range, Nevada, DOE/NV-443. Las Vegas, NV.

DOE/NV, 1996b. Final Environmental Impact Statement for the Nevada Test Site and Off-site Locations in the State of Nevada, Volume I, DOE/EIS 0243. Las Vegas, NV.

DOE/NV, 1996c. Industrial Waste Quality Assurance ProjectPlan, DOE/NV-372. Las Vegas, NV.

DOE/NV, 1996d. Nevada Environmental Restoration Project, Industrial Sites, Quality Assurance Project Plan, Nevada Test Site, Revision 1. Las Vegas, NV.

DOE/NV, 1998a. Corrective Action Decision Document for CAU 427: Area 3 Septic Systems 2\& 6, Tonopah Test Range, Nevada, Revision 0, April 1998, DOE/NV--509.

DOE/NV, 1998b. Corrective Action Plan for Corrective Action Unit 427: Area 3 Septic Waste Systems 2 \& 6 Tonopah Test Range, Nevada, Revision 0, November 1998, $\mathrm{DOE} / \mathrm{NV} / 11718--248$.

DOE/NV, 1998c. Nevada Environmental Restoration Project, Health and Safety Plan, Revision 3. Las Vegas, NV.

Federal Facility Agreement and Consent Order, see FFACO.

FFACO, 1996, Agreed to by the Nevada Division of Environmental Protection, the U.S. Department of Energy, and the U.S. Department of Defense. 
THIS PAGE INTENTIONALLY LEFT BLANK 


\section{APPENDIX A \\ SEPTAGE DISPOSAL DOCUMENTATION}


THIS PAGE INTENTIONALLY LEFT BLANK 


\section{NUCOUNT: UMENAREA \\ WASTE MA IFESI \\ LOAD NUMBER $\angle S-99-3-5$ \\ (Load Numbers swil be assigned by the Nye Joutly Public Works Dopatment)}

Trusponcrs Compañ Lians:

Disposal Date:

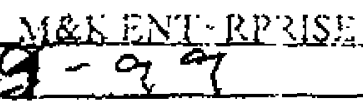

\section{GENERATOXS OF WASTE}

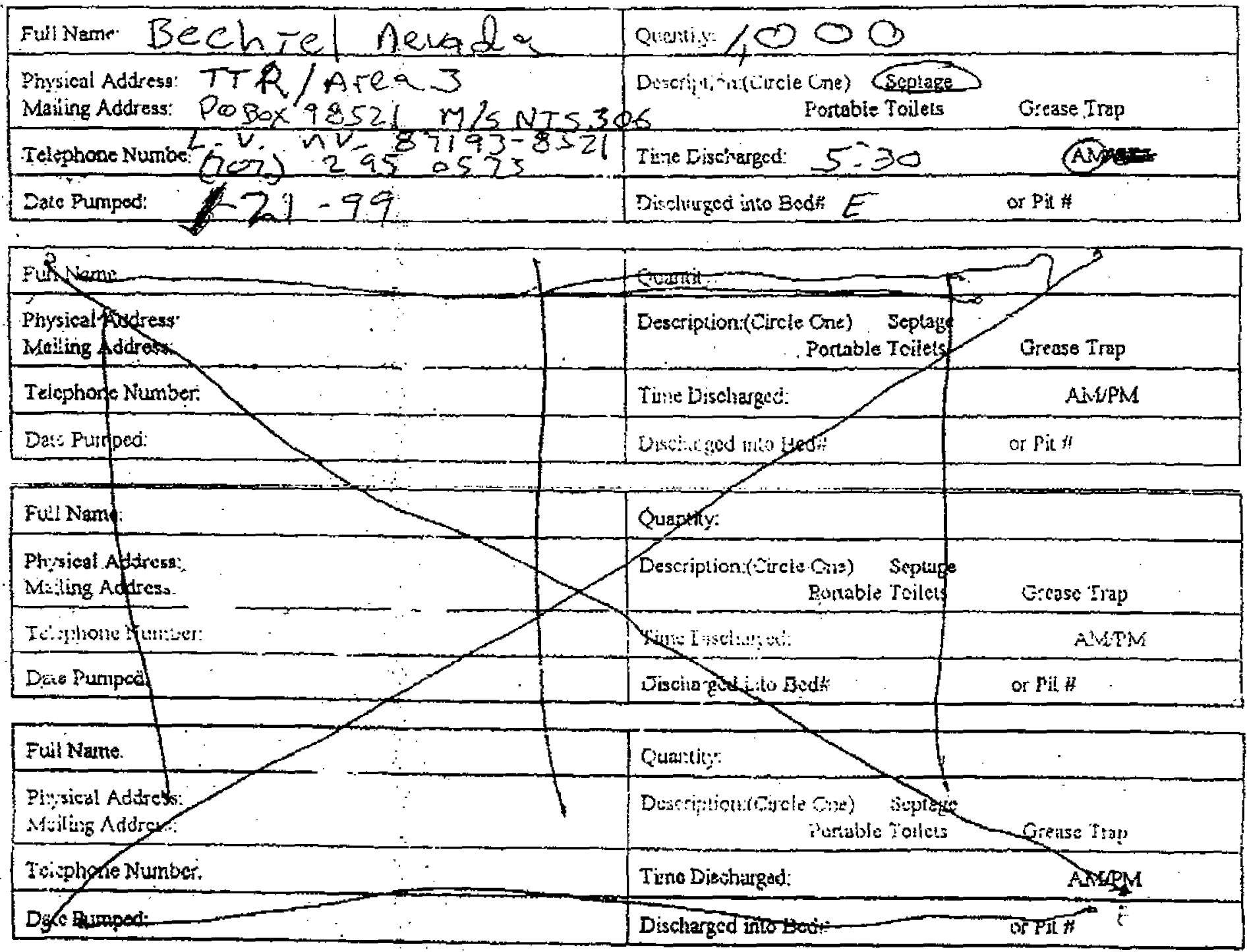

TOTAI GALLONS FOR THIS LOAD

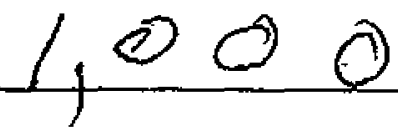

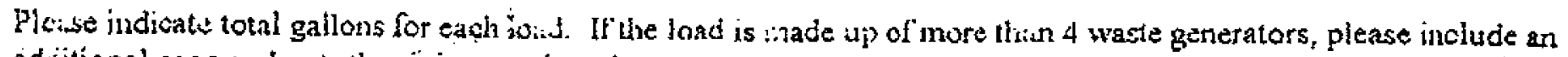
adcitional page and note that it is a continualion pagt-

Hatiler Siguature

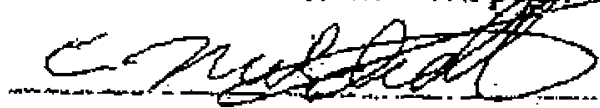


THIS PAGE INTENTIONALLY LEFT BLANK 
APPENDIX B

ENGINEERING AS-BUILT DRAWINGS 
THIS PAGE INTENTIONALLY LEFT BLANK 


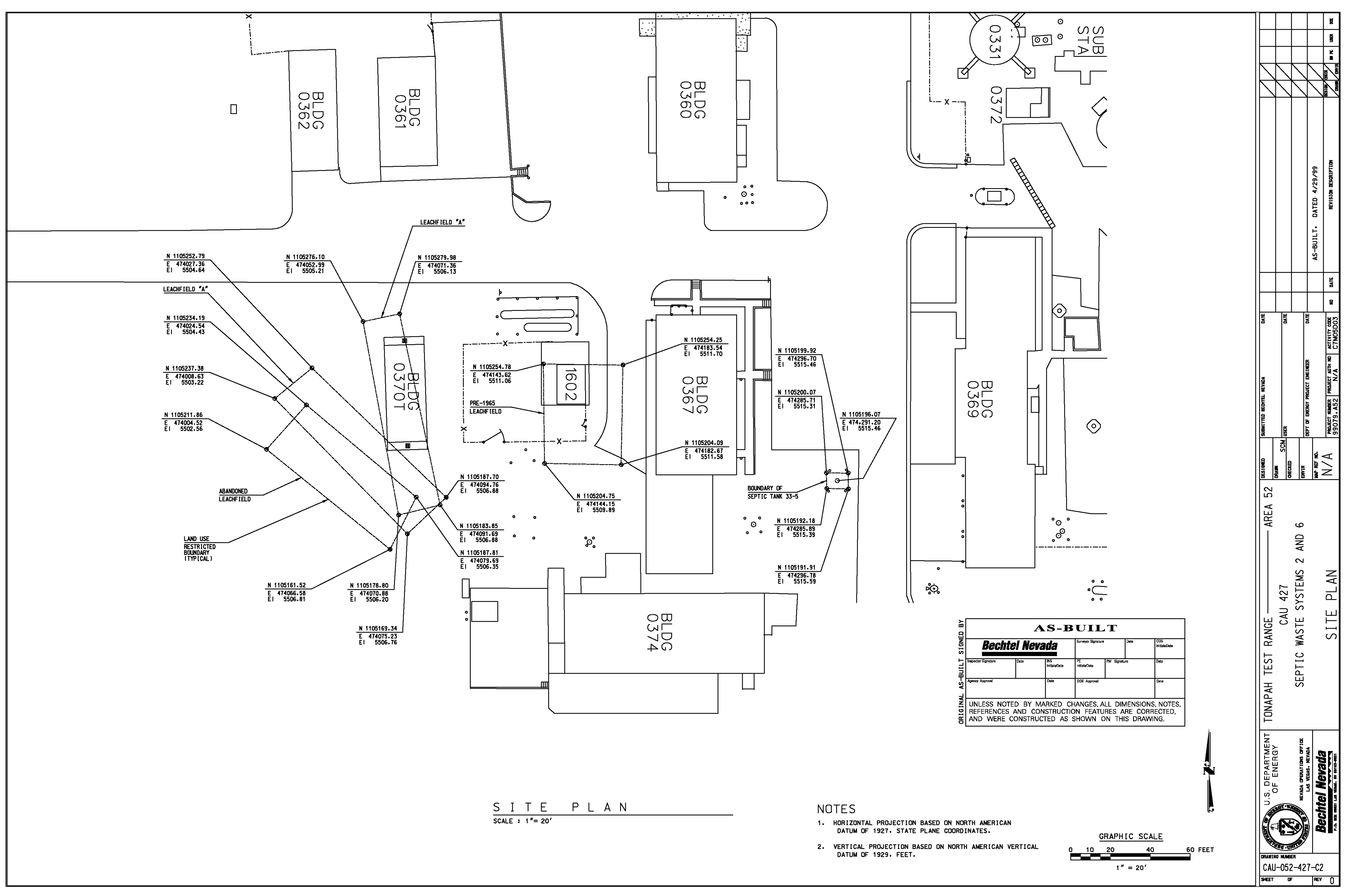




\section{APPENDIX C}

\section{USE RESTRICTION DOCUMENTATION}


THIS PAGE INTENTIONALLY LEFT BLANK 
1 
THIS PAGE INTENTIONALLY LEFT BLANK 


\section{CAU Use Restriction Information}

CAU Number/Description: CAU 427: Septic Waste Systems 2 \& 6

Applicable CAS Numbers/Descriptions: CAS Number 03-05-002-SW06, which includes Pre-1965 Leachfield. CAS Number 03-05-002-SW02, which includes Leachfield A. Leachfield B, Abandoned Leachfield, and Septic Tank 33-5.

Contact (organization/project): J. L. Appenzeller-Wing, DOE/NV Industrial Sites Project Manger

Surveyed Area (UTM coordinates; Zone 11, NAD 27):for additional information, see attached

Pre-1965 Leachfield: Engineering As-Builts $4181928.2645 \mathrm{mN} \quad 521472.5660 \mathrm{mE} ; \quad 4181928.1475 \mathrm{mN} \quad 521484.7309 \mathrm{mE}$; $4181912.8639 \mathrm{mN} \quad 521484.5215 \mathrm{mE} ; \quad 4181913.0220 \mathrm{mN} \quad 521472.7806 \mathrm{mE}$

Leachfield A: $4181934.3591 \mathrm{mN} \quad 521444.9273 \mathrm{mE} ; \quad 4181935.8653 \mathrm{mN} \quad 521450.5218 \mathrm{mE}$; $4181906.5971 \mathrm{mN} \quad 521456.8183 \mathrm{mE} \quad 4181905.0347 \mathrm{mN} \quad 521450.4858 \mathrm{mE}$

Leachfield B: $4181907.7724 \mathrm{mN} \quad 521457.7504 \mathrm{mE} ; \quad 4181902.1563 \mathrm{mN} \quad 521451.8205 \mathrm{mE}$; $4181922.8159 \mathrm{mN} \quad 521431.4517 \mathrm{mE} ; \quad 4181927.5322 \mathrm{mN} \quad 521437.1437 \mathrm{mE}$

Abandoned Leachfield: $4181921.8619 \mathrm{mN} \quad 521436.3040 \mathrm{mE} ; \quad 4181915.0371 \mathrm{mN} \quad 521430.2283 \mathrm{mE}$ $4181899.7655 \mathrm{mN} \quad 521449.1930 \mathrm{mE} ; \quad 4181907.7901 \mathrm{mN} \quad 521453.1591 \mathrm{mE}$

Septic Tank 33-5: $4181909.2742 \mathrm{mN} \quad 521519.3051 \mathrm{mE} ; \quad 4181911.7164 \mathrm{mN} \quad 521519.2704 \mathrm{mE}$ $4181911.7491 \mathrm{mN} \quad 521515.9228 \mathrm{mE} \quad 4181909.3469 \mathrm{mN} \quad 521515.9854 \mathrm{mE}$

Site Monitoring Requirements: Site inspections conducted by ER staff will document indications of subsidence, erosion, and unauthorized use of soil and asphalt covers. Inspections will document the condition of markers and warning signs. Site monitoring will be used to determine if maintenance, repairs, and/or modifications to use restriction administrative controls are needed and/or if termination of post-closure inspections can be proposed.

Survey Date _March 11, 1999 Survey Method (GPS, etc.)__Wilde TC 1600 Total Station

Required Frequency (quarterly, annually?): Annually

If Monitoring Has Started, Indicate Last Completion Date: N/A 


\section{Use Restrictions}

The future use of any land related to this Corrective Action Unit (CAU), as described by the above surveyed location, is restricted from any DOE or Air Force activity that may alter or modify the containment control as approved by the state and identified in the CAU Closure Report or other CAU documentation unless appropriate concurrence is obtained in advance.

Comments: See the Closure Report for additional information on the condition of the site(s) and any monitoring and/or inspection requirements.

Submitted By: Jeff Smith

Date: July 2.1999

cc with copy of survey map (paper and digital (.dgn) formats):

CAU Files ( 2 copies) 
USAF ACKNOWLEDGMENT LETTER 
THIS PAGE INTENTIONALLY LEFT BLANK 


\section{DEPARTMENT OF THE AIR FORCE \\ HEADQUARTERS 99TH AIR BASE WING (ACC) \\ NELLIS AIR FORCE BASE, NEVADA}

Ms. Eloisa Hopper

Director, Environmental Management

4349 Duffer Drive, Suite 1601

Nellis AFB NV 89191-7007

JUL 021999

Ms. Runore C. Wycoff

Director, Environmental Restoration Division

DOE Nevada Operations Office

P.O. Box 98518

Las Vegas NV 89193-8518

\section{RECORDATION OF CORRECTIVE ACTION UNIT (CAU) 427}

Nellis Air Force Base (Nellis) has recorded the U. S. Department of Energy's (DOE) Use Restriction Information for Corrective Action Unit (CAU) 427. The information was placed in the Geographic Information System at the Range Management Office, Nellis.

Please contact me at $652-4123$ if you have any questions.

Sincerely

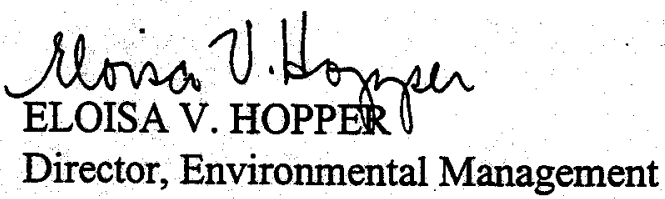

cc:

NDEP

HQAWC RMO/RML

HQ AWFC/JAV 
THIS PAGE INTENTIONALLY LEFT BLANK

C-2 


\section{APPENDIX D}

\section{POST-CLOSURE INSPECTION PLAN AND MAINTENANCE RECORD}




\section{POST-CLOSURE INSPECTION CHECKLIST}


THIS PAGE INTENTIONALLY LEFT BLANK 


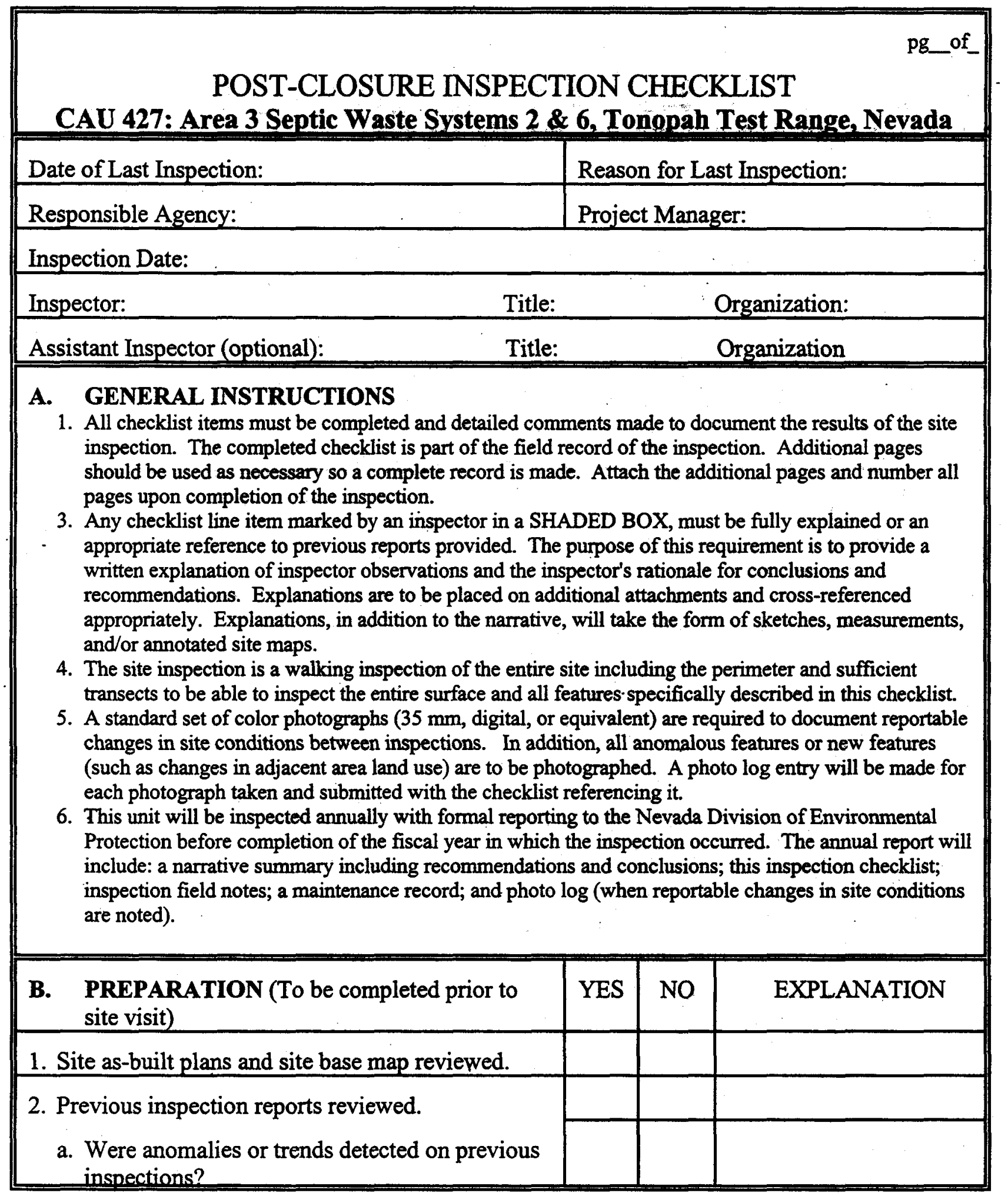




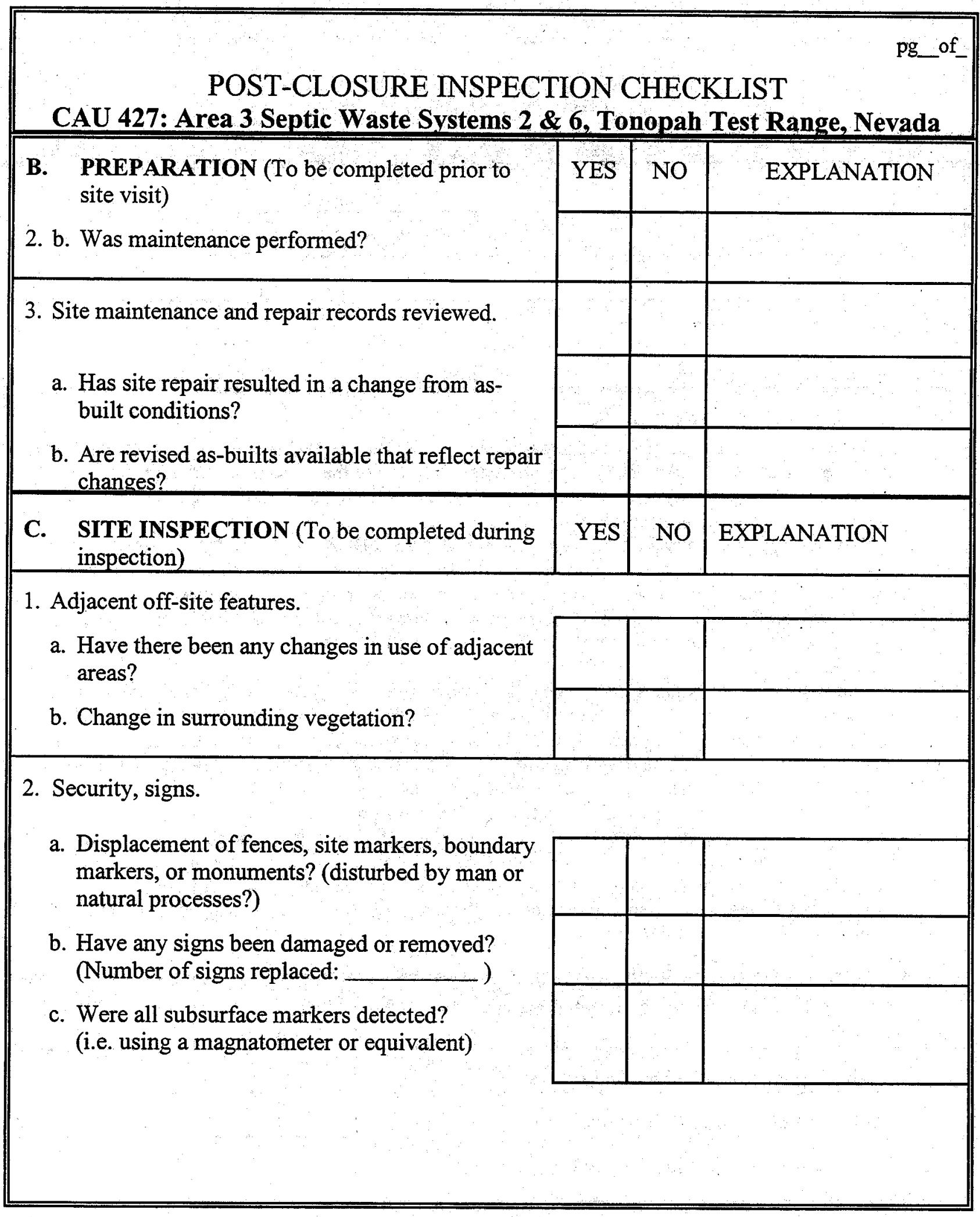




\section{POST-CLOSURE INSPECTION CHECKLIST}

CAU 427: Area 3 Sentic Waste Systems 2 \& 6. Tononah Test Range Nevada

3. Soil/asphalt cover.

a. Is there evidence of settling?

b. Is there cracking?

c. Is there evidence of erosion near the use restriction boundaries?

d. Is there evidence of animal burrowing?

f. Is there vegetation?

g. Do natural processes threaten to integrity of any cover or site marker?

$h$. Is there evidence suggesting unauthorized excavations have taken place?

h. Other?

\begin{tabular}{|l|l|l|} 
YES & NO & \multicolumn{2}{l|}{ EXPLANATION } \\
\hline & & \\
\hline & & \\
\hline & & \\
& & \\
\hline & & \\
\hline & & \\
\hline & & \\
\hline & & \\
\hline & & \\
\hline
\end{tabular}

4. Photo Documentation

a. Has a photo log been prepared?

c. Number of photos taken (

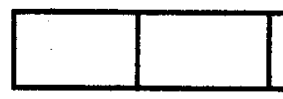
)

\section{FIELD CONCLUSIONS}

1. Is there an imminent hazard to the integrity of the unit? (Immediate report required)

Person/Agency to whom report made:

2. Are more frequent inspections required?

3. Are existing maintenance/repair actions satisfactory?

4. Is other maintenance/repair necessary?

5. Rationale for field conclusions: 


\begin{tabular}{|c|c|}
\hline \multicolumn{2}{|c|}{$\begin{array}{c}\text { POST-CLOSURE INSPECTION CHECKLIST } \\
\text { CAU 427: Area 3 Septic Waste Svstems 2 \& 6. Tonopah Test Range, Nevada }\end{array}$} \\
\hline \multicolumn{2}{|l|}{ E. CERTIFICATION } \\
\hline \multicolumn{2}{|c|}{$\begin{array}{l}\text { I have conducted an inspection of the CAU } 427 \text {, Area } 3 \text { Septic Systems } 2 \& 6 \text {, at the TTR } \\
\text { following the Post-Closure Inspection Plan* as recorded on this checklist, attached sheets, field } \\
\text { notes, photo logs, and photographs. } \\
\text { *see the CAU } 427 \text { Closure Report for post-closure inspection requirements }\end{array}$} \\
\hline Chief Inspector's Signature: & Printed Name: \\
\hline Title: & Date: \\
\hline
\end{tabular}




\section{POST-CLOSURE MAINTENANCE RECORD}


THIS PAGE INTENTIONALLY LEFT BLANK 


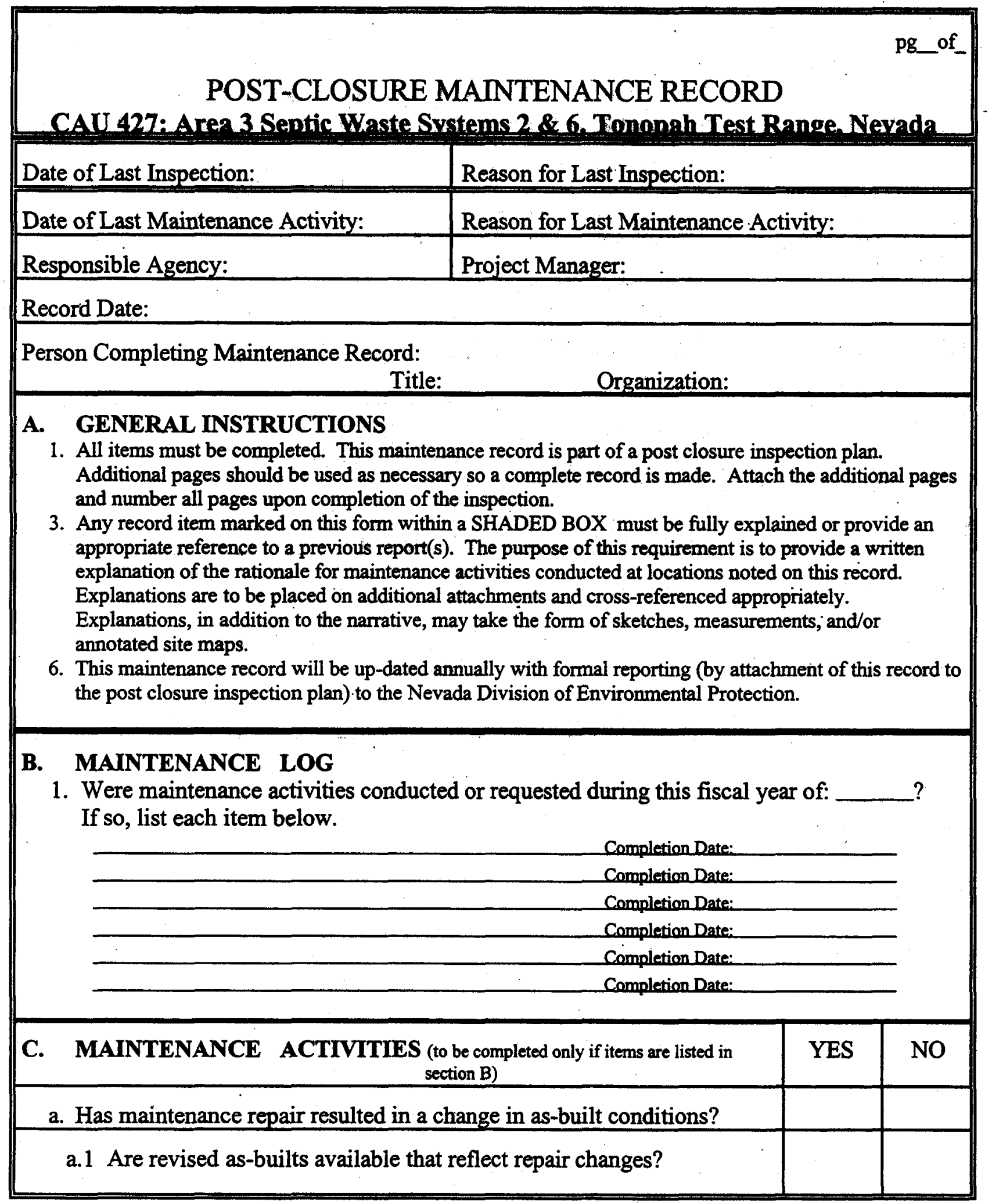




\begin{tabular}{|c|c|c|}
\hline $\begin{array}{r}\text { POST- } \\
\text { CAU 427: Area 3 Se } \\
\end{array}$ & $\begin{array}{l}\text { TENANCE RECC } \\
\mathbf{2} \text {. Tonopah Te }\end{array}$ & $\begin{array}{l}\text { pg_of } \\
\text { vada }\end{array}$ \\
\hline $\begin{array}{l}\text { b. Were maintenance act } \\
\text { containment control? }\end{array}$ & onse to a breach in & \\
\hline $\begin{array}{l}\text { c. Were maintenance acti } \\
\text { inspection requesting } \mathrm{r}\end{array}$ & 90 days of the & \\
\hline $\begin{array}{l}\text { d. Was the source causin } \\
\text { identified and eliminat }\end{array}$ & entioned activity(ies) & \\
\hline D. CERTIFICATION & & \\
\hline $\begin{array}{l}\text { I have conducted an inspecti } \\
\text { following the Post-Closure I } \\
\text { notes, photo logs, and photo } \\
\text { *see the CAU } 427 \text { Closure Repo }\end{array}$ & $\begin{array}{l}\text { rded on this checklist, } \\
\text { reptic Systems } 2 \text {, } \\
\text { on requirements }\end{array}$ & in \\
\hline Chief Inspector's Signature: & Printed Name: & \\
\hline Title: & Date: & \\
\hline
\end{tabular}


APPENDIX E

\section{PROJECT PHOTOGRAPHS}


THIS PAGE INTENTIONALLY LEFT BLANK 


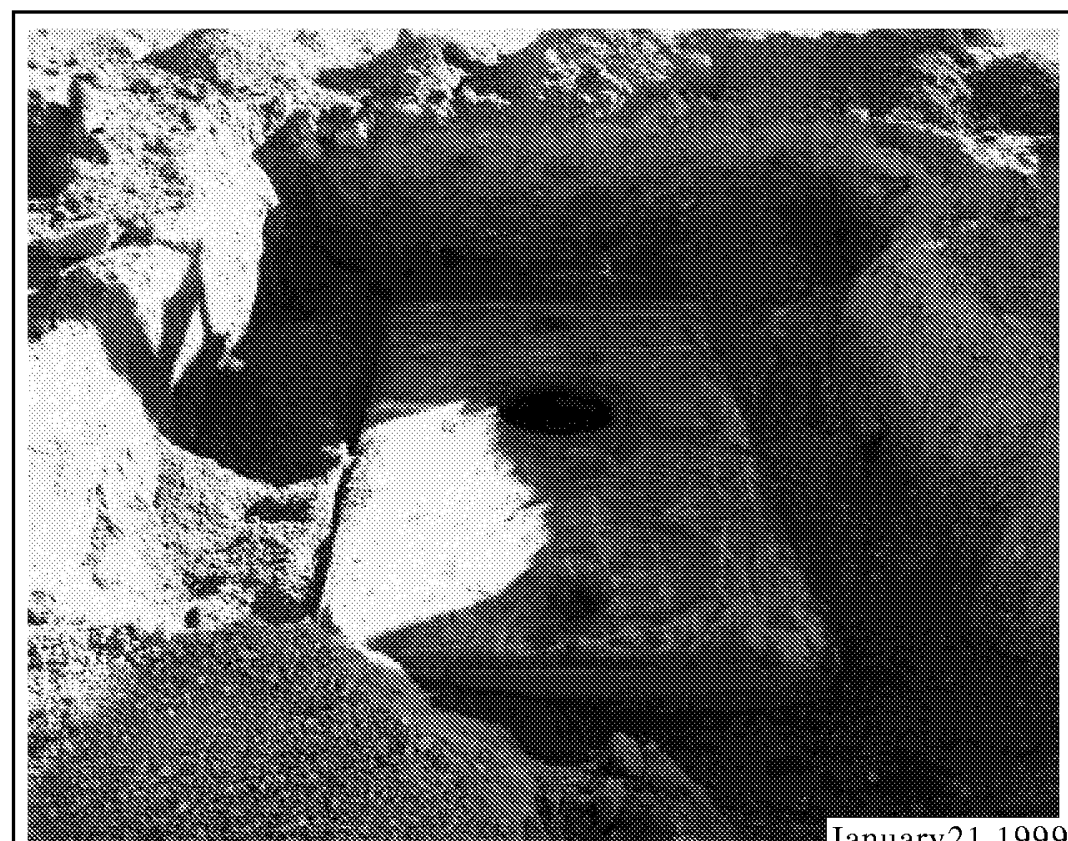

January21,1999

SEPTIC TANK 33-5

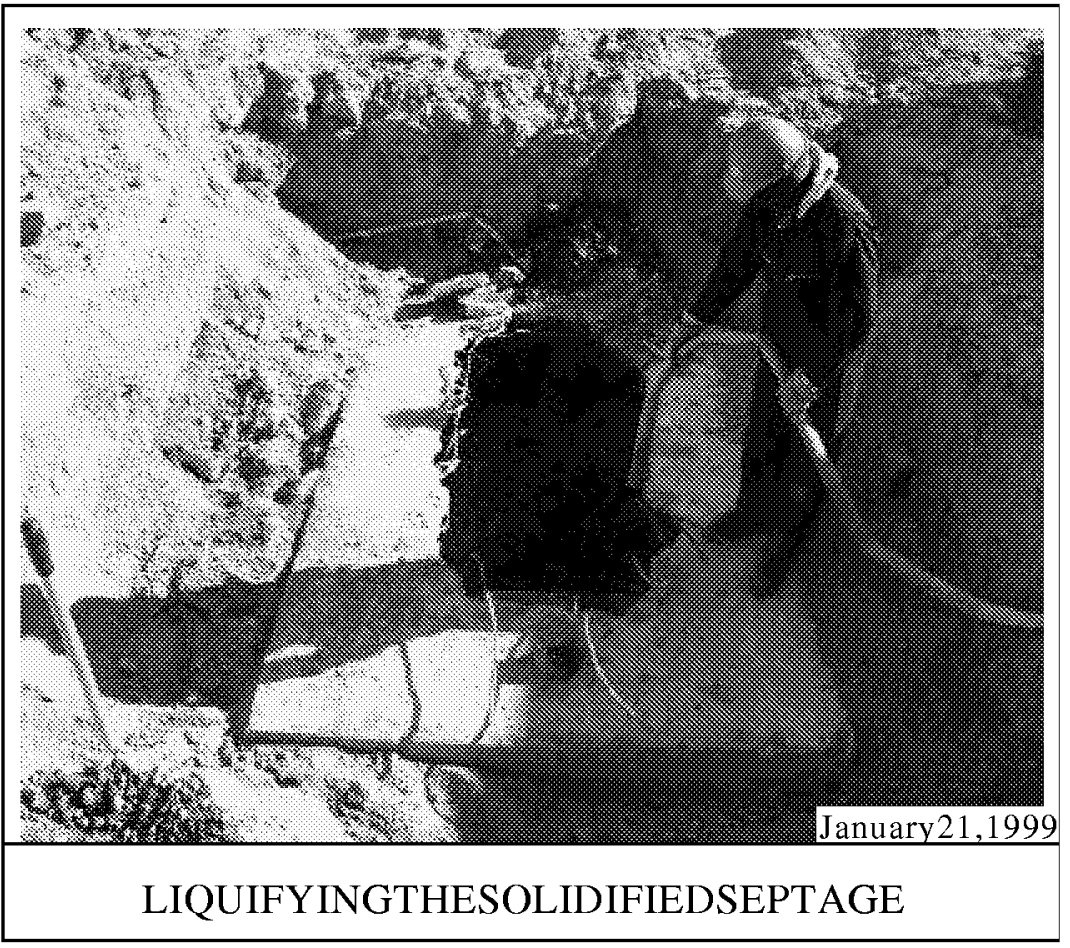

FIGURE E-1

PHOTODOCUMENTATIONOF

JANUARY 21-22, 1999,CLOSUREACTIVITIES 
Date: August 1999

\section{THIS PAGE INTENTIONALLY LEFT BLANK.}



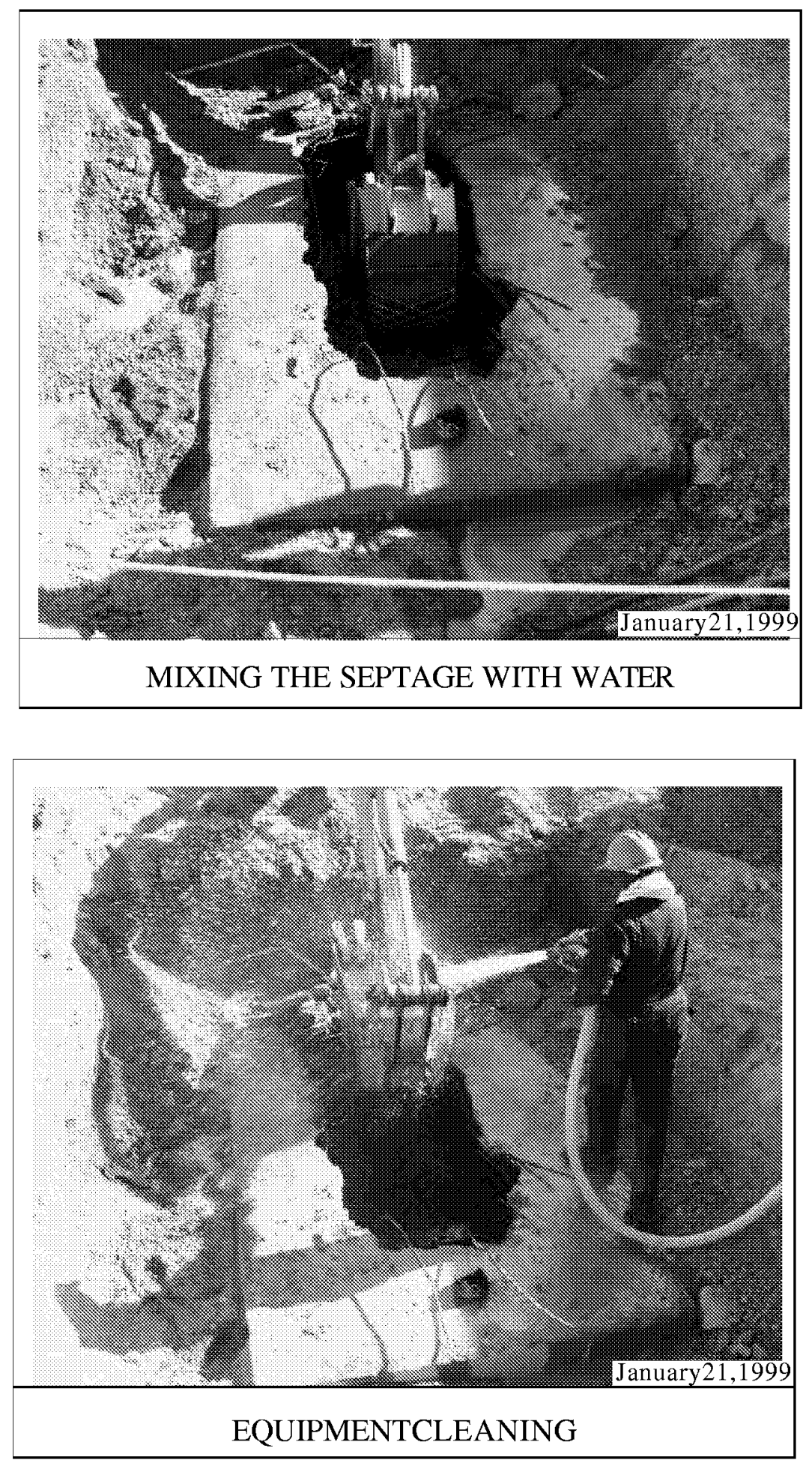

FIGURE E-2

PHOTODOCUMENTATIONOF

JANUARY 21-22, 1999,CLOSUREACTIVITIES 
Date: August 1999

\section{THIS PAGE INTENTIONALLY LEFT BLANK.}



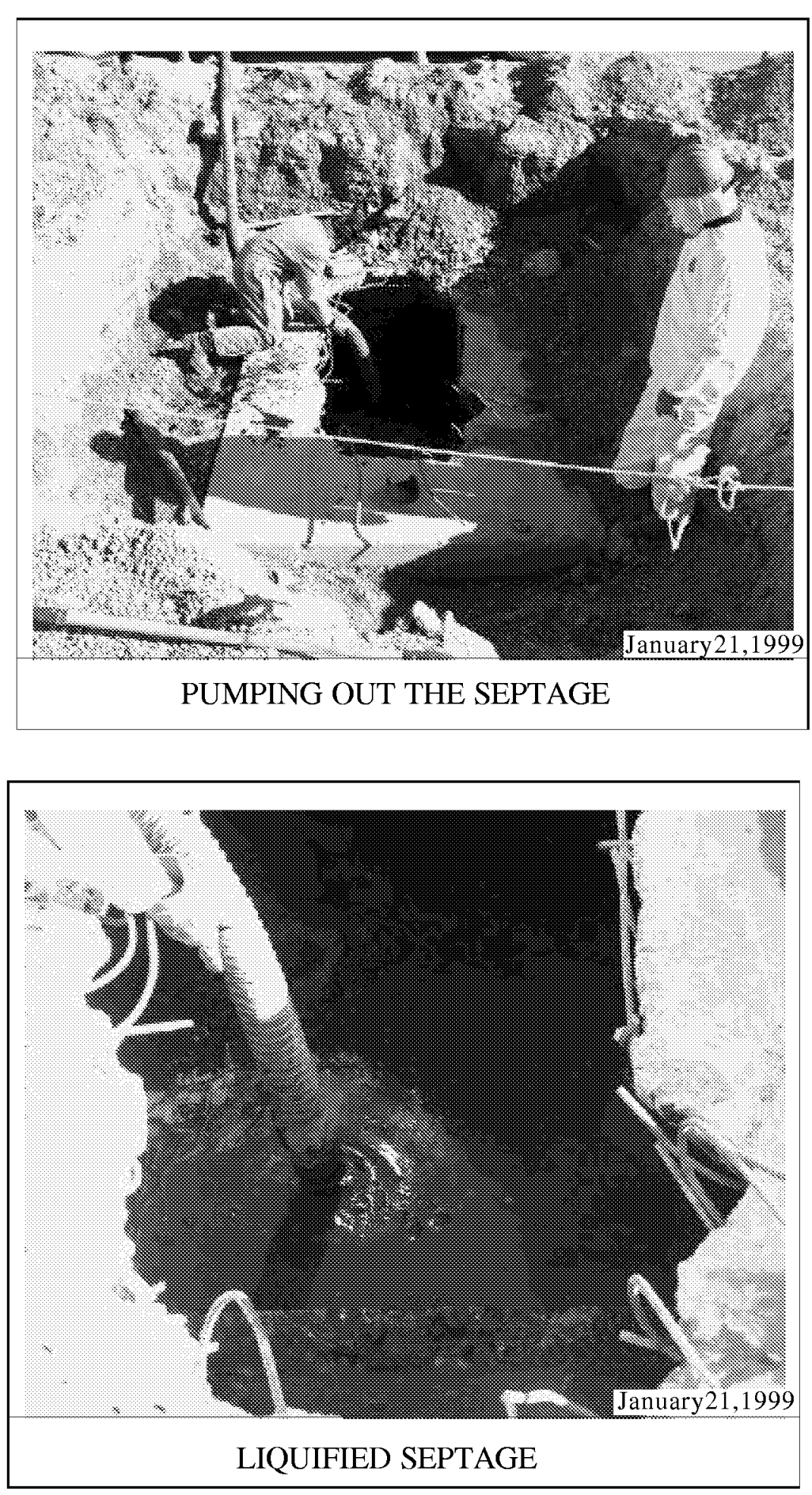

FIGURE E-3

PHOTODOCUMENTATIONOF

JANUARY 21-22, 1999,CLOSUREACTIVITIES 
Date: August 1999

\section{THIS PAGE INTENTIONALLY LEFT BLANK.}



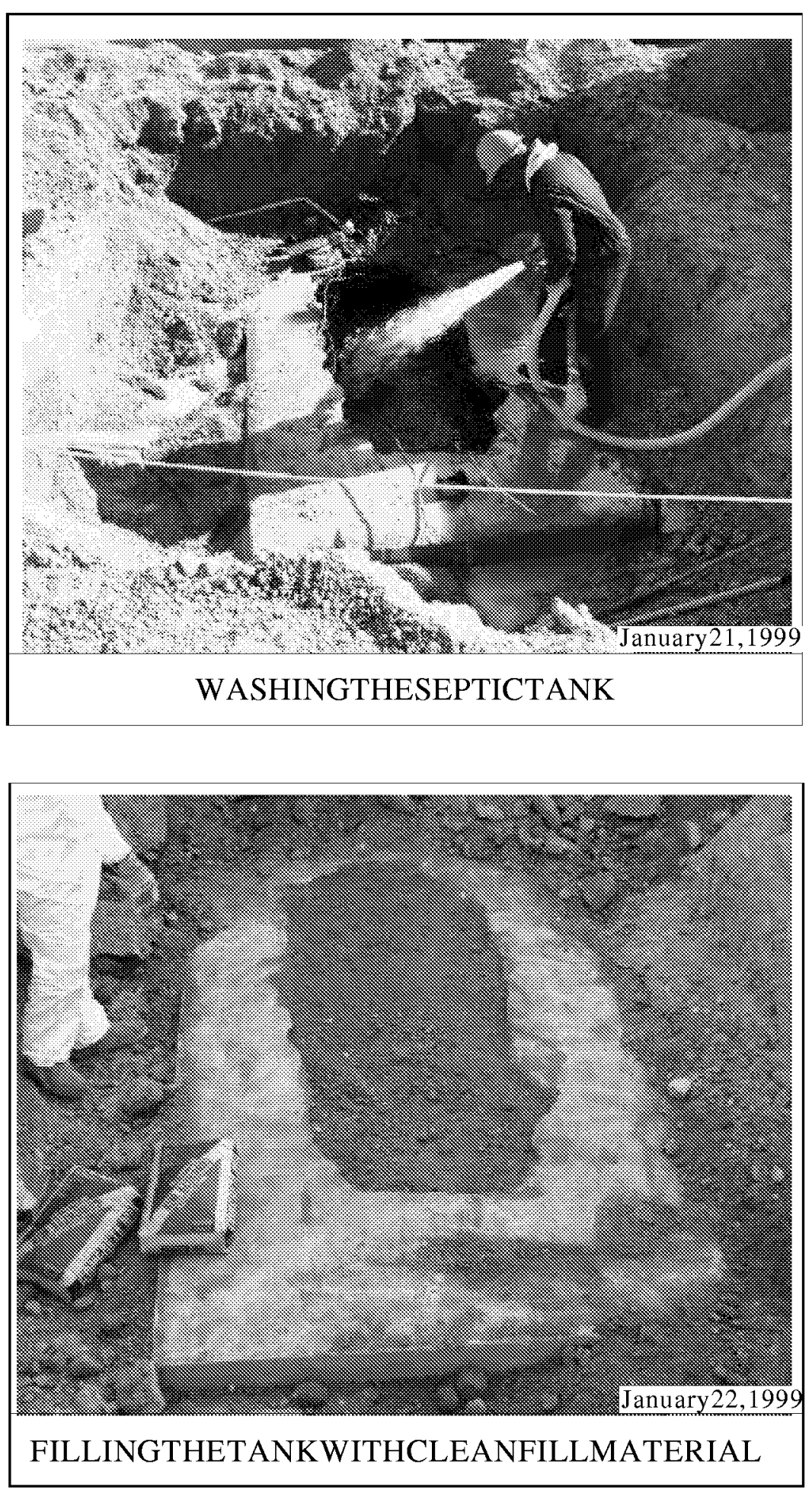

FIGURE E-4

PHOTODOCUMENTATIONOF

JANUARY 21-22, 1999,CLOSUREACTIVITIES 
Date: August 1999

\section{THIS PAGE INTENTIONALLY LEFT BLANK.}



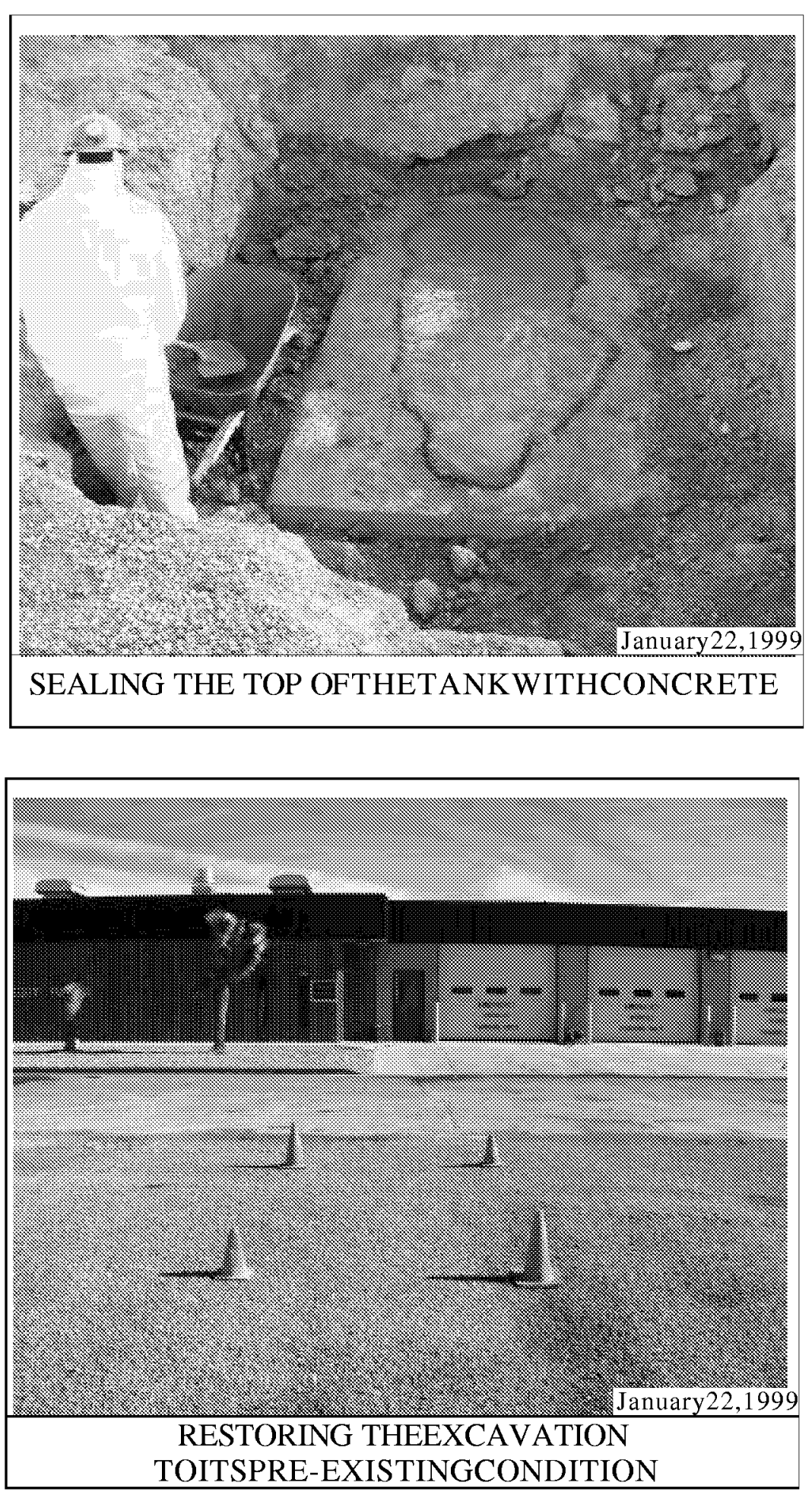

FIGURE E-5

PHOTODOCUMENTATIONOF

JANUARY 21-22, 1999,CLOSUREACTIVITIES 
Date: August 1999

\section{THIS PAGE INTENTIONALLY LEFT BLANK.}



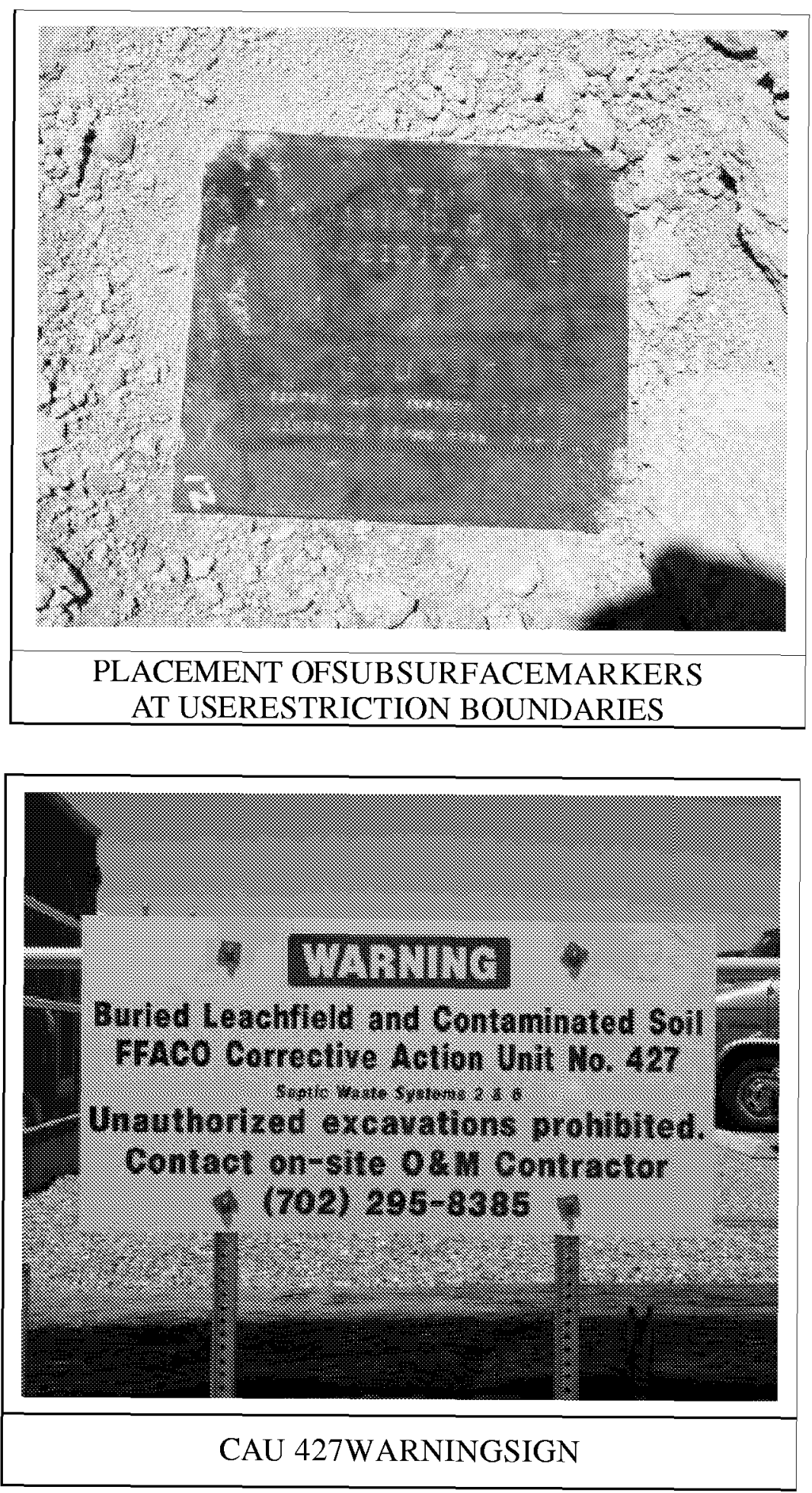

FIGURE E-6

PHOTODOCUMENTATIONOF

JUNE 29, 1999, CLOSURE ACTIVITIES 
Date: August 1999

\section{THIS PAGE INTENTIONALLY LEFT BLANK.}




\section{DISTRIBUTION LIST}


THIS PAGE INTENTIONALLY LEFT BLANK 


\section{DISTRIBUTION LIST}

Bureau of Federal Facilities

Division of Environmental Protection

333 W. Nye Lane, Room 13B

Carson City, NV 89706-0866

P. L. Liebendorfer

Las Vegas Office

\section{Bureau of Federal Facilities}

Division of Environmental Protection

555 E. Washington, Suite 4300

Las Vegas, NV 89101-1043

Office Administrator

\section{Controlled Copies}

2

1

1

Uncontrolled Copies

U.S. Department of Energy, Nevada Operations Office

P.O. Box 98518

Las Vegas, NV 89193-8518

J. L. Appenzeller-Wing

K. J. Cabble

Public Reading Facility

Technical Information Resource Center

\section{U.S. Department of Energy,}

Office of Scientific and Technical Information

175 Oak Ridge Turnpike

P.O. Box 62

Oak Ridge, TN 37831-0062 


\section{DISTRIBUTION LIST (continued)}

Bechtel Nevada

Uncontrolled Copies

P.O. Box 98521

Las Vegas, NV 89193-8521

Correspondence Control

F. E. Cenicola

D. K. Cowser

S. J. Nacht

J. G. Nelson

J. L. Smith

IT Corporation

P.O. Box 93838

Las Vegas, NV 89193-3838

K. C. Beach

R. B. Jackson

M. E. Todd 


\section{COMMENT RESPONSES}




\section{THIS PAGE INTENTIONALLY LEFT BLANK}




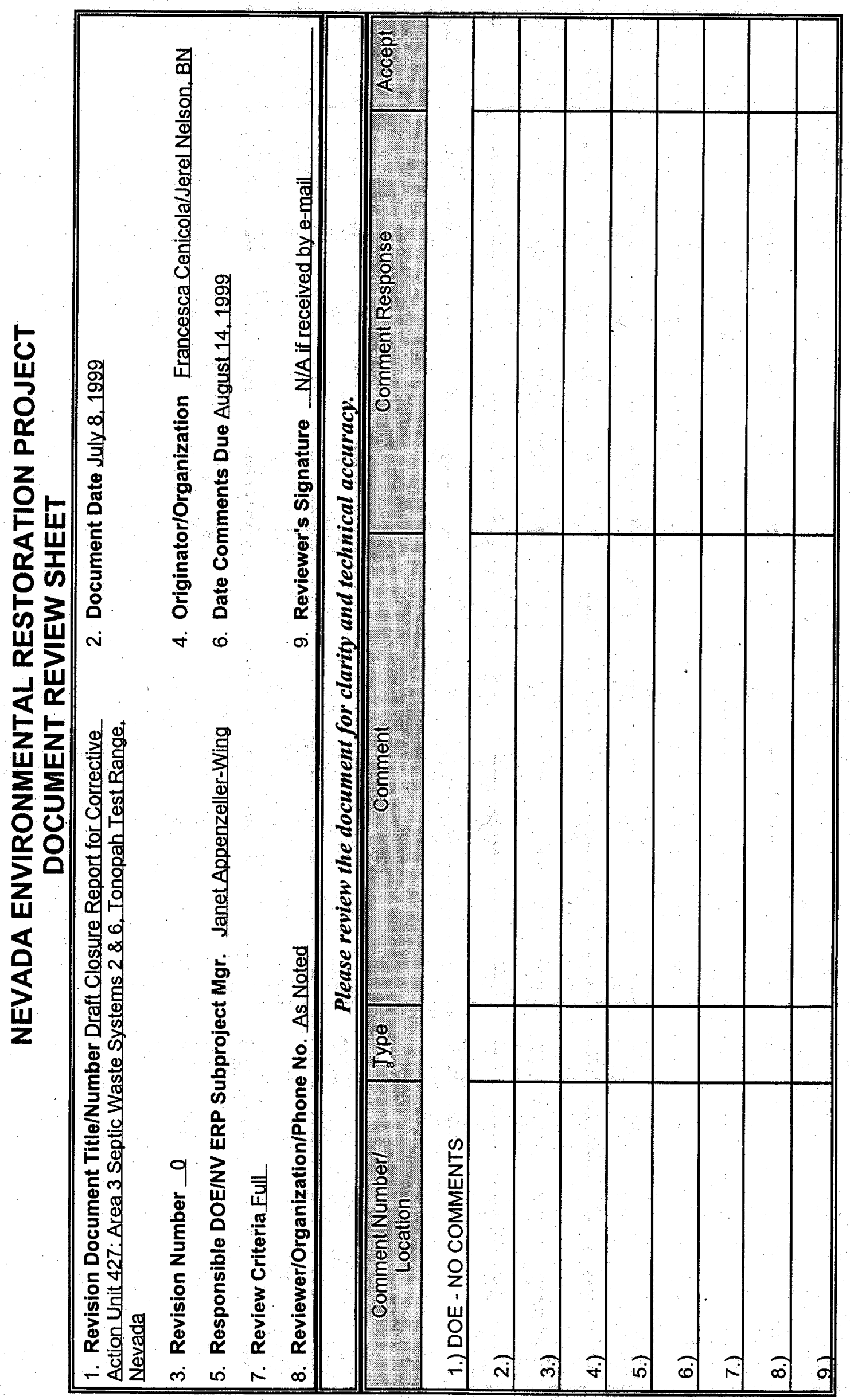




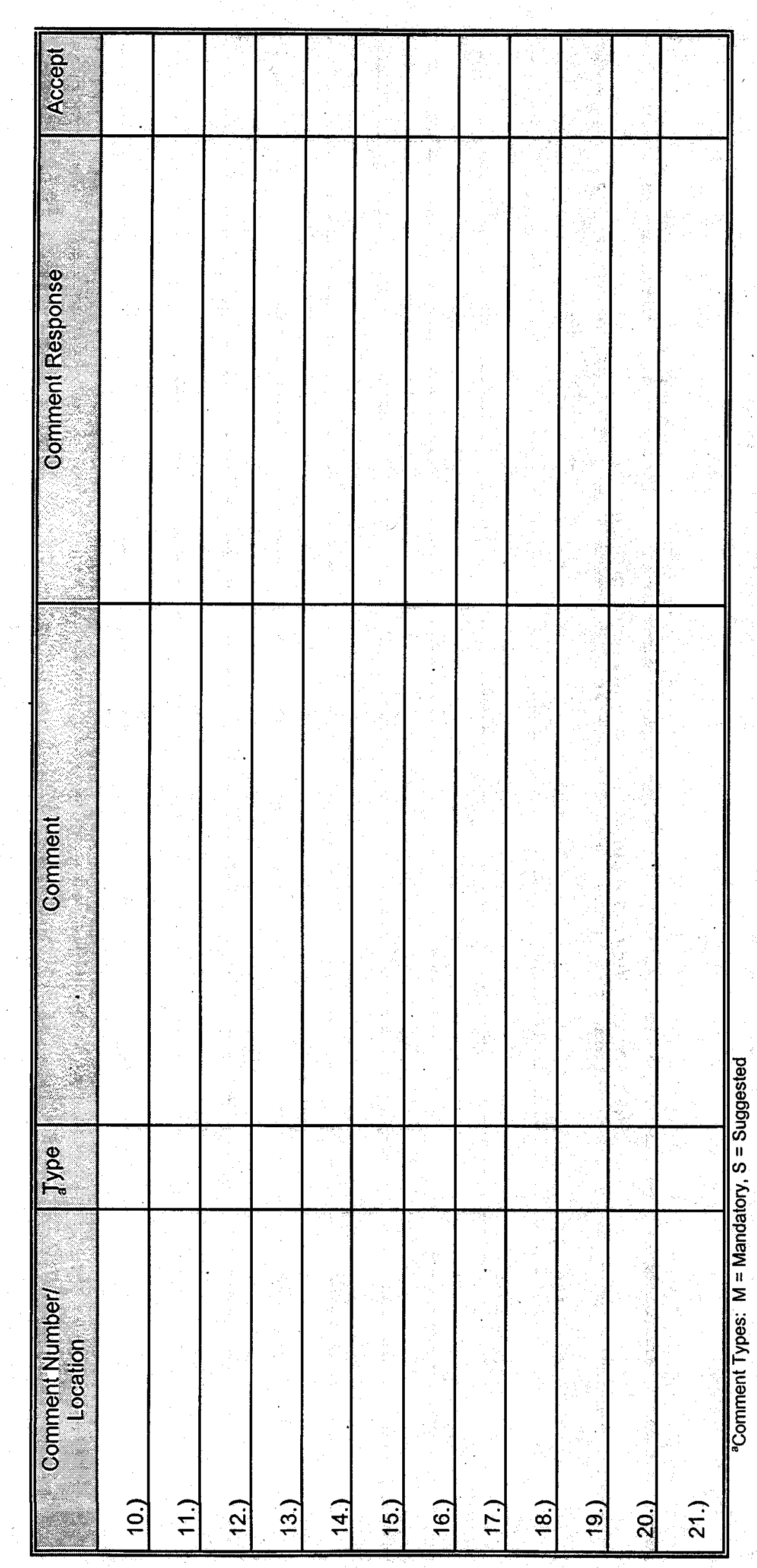

